\title{
THE MECHANICS OF GLACIER FLOW
}

\section{I SCUSS I O N}

The following discussion took place after the reading of Dr. F. F. Nye's paper on "The Mechanics of Glacier Flow" at a meeting of the British Glaciological Society held at University College, London. The paper was published in the "Journal of Glaciology," Vol. 2, No. 12, 1952, p. 82-93.

Mr. M. M. Miller: Could bed-rock hummocks or transverse rock thresholds beneath a glacier serve as one of the more important "tripping mechanisms" for the primary development of shearing along selected planes:

Dr. J. F. NyE: In a zone of compressive flow the precise spot at which thrusting began might well be some irregularity in the bed. Thrusting might also be started when some weak surface in the ice itself, suitably orientated, enters a region of compressive flow.

Mr. Milier: Perhaps shear planes do not always extend to the bottom of the glacier. In glaciers of sufficient thickness could they pass into a zone where "plastic adjustment" would be the controlling factor in the release of stresses set up within the glacier at depth?

Dr. Nye: I agree. Not only might they extend from the top surface downwards without reaching the bottom, but I imagine it would be possible for them to start at the bottom and extend upwards without reaching the top. There might also be internal shear faults which do not penetrate to either surface.

Mr. J. M. HARTOG : In making any general assumptions on the nature of an ice cap as a prelude to mathematical analysis of its behaviour, it is important to consider its thermal regime. In the Arctic, glaciers have been found which are isothermal to a great depth, while others have temperatures considerably below zero even $100 \mathrm{ft}$. below the surface.

Mr. G. Seligmax: Would anybody present throw any further light on the question of crevasse depths? In practice they are not found more than $30 \mathrm{~m}$. ( $100 \mathrm{ft}$.) deep in temperate glaciers. To what extent do those of Arctic glaciers differ?

Mr. Miller: In Greenland and Antarctica, crevasses have been seen to exceed $120 \mathrm{ft}$. in depth. On the other hand in the Alaskan glaciers, or in the Alps, this figure seems to be the absolute deepest limit. By actual hand measurement on the Taku Glacier, and the Seward Glaciers in S.E. Alaska, we have found them never to exceed roo ft. and most of the deeper ones are no more than $90 \mathrm{ft}$. By seismic soundings on the Taku in 1949, we determined the maximum depth of fracture in the surface "tensile zone" to be $120 \mathrm{ft}$. This, of course, took into account the very thin V-shaped wedge of fracture which could not normally be measured by hand line at the bottom of the crevasses.

On the matter of temperature effects concerning these supposed differences, the less viscosity found in very cold sub-zero or polar ice may be of considerable influence. Once a fracture occurs to depth in such ice it could conceivably be more difficult for the crevasses to close than in the case of the probably less rigid walls of a crevasse in an isothermal glacier.

Dr. NyE: To put the same thing in another way, the curve A in Fig. I ${ }^{*}$ depends on temperature. The lower the temperature the higher the curve. In general, therefore, higher shear stresses may exist in polar than in temperate glaciers. Thus, in theory, the tensile layer should extend deeper into polar glaciers, and crevasses once formed should be more sluggish in closing up. It is interesting to hear that there is some evidence for these effects in practice. 
Mr. W. V. Lewis (Department of Geography, Cambridge) : May not the crevasses in Greenland glaciers be deeper than those in the Alps and Norway partly because of the greater speed of opening induced by tension effects between the quickly moving ice and the valley sides?

Dr. NyE: That would certainly seem to be a possibility. Other things being equal, the faster a glacier flows the greater the shear stress component $\tau_{z x}$ (Fig. 9) on its surface towards the margins. The greater then is the marginal tensile stress $(\$ 5)$. The stress will thus remain tensile to greater depth before becoming neutralized by the hydrostatic pressure, and the marginal crevasses could be deeper.

Dr. G. G. Meyerhof (Building Research Station, D.S.I.R.) : An indication of the maximum theoretical depth $h$ to which crevasses, irrespective of how they were formed, will remain open can be obtained from plastic theory (e.g. K. Terzaghi, Theoretical Soil Mechanics, Wiley, New York: 1943, p. 152).

Let $h_{0}=k / \rho g$

where

$k=$ yield stress in pure shear

$g=$ gravitational acceleration

$\rho=$ density ;

then provided the distance $l$ between adjacent crevasses is greater than ${ }_{4} h_{0}$, it may be shown that

$$
h=4 h_{0}
$$

Similarly if the distance $l<4 h_{0}$, then

$$
h=2 h_{0}+\frac{l}{2} \text {, approximately }
$$

which gives a minimum depth of

$$
h=2 h_{0}
$$

for a very close spacing of crevasses.

Since for glaciers $k$ is between $0.5 \times 10^{6}$ and $1.5 \times 10^{6}$ dynes $\mathrm{cm} .{ }^{2}$ as mentioned by the author, the maximum theoretical depth would vary between about 10 and $70 \mathrm{~m}$. depending on the values of $k$ and $l$. These estimates appear to be in fair agreement with the observed depths mentioned by previous speakers.

Dr. NyE: I am doubtful about the application of Dr. Meyerhof's equations (I) and (2) to this problem. At a depth $d$ the two extreme principal stresses in the wall of an open vertical crevasse would be a pressure, $A+\rho g d$, acting vertically, and $A$ acting horizontally $(A=$ atmospheric pressure). This gives a maximum shear stress of $\frac{1}{2} \rho g d$. At points below a depth $2 h_{0}$, therefore, the ice is on the point of yielding. However, in the soil-mechanics calculations yielding is only supposed to occur if the average shear stress on a potential failure surface reaches the critical value, and, if $l>4 h_{0}$, as Dr. Meyerhof points out, this only happens when $d=4 h_{0}$. The failure surface in this case is a plane inclined at 45 degrees to the vertical which runs up from the bottom of the crevasse to the surface. But I am not convinced that shearing along such a plane is the way in which collapse would occur. At points below a depth of $2 h_{0}$ it seems unlikely that the restraint exerted by the surroundings would be enough to prevent the ice from being squeezed out plastically. In view of the fact that ice has no sharp yield point I should think that the most likely method of failure would be a bulging out of the wall of the crevasse, the bulging becoming more pronounced the greater the depth. $2 h_{0}$ is then a rough measure of the depth at which this bulging becomes rapid.

Mr. Hartog: Applying the formula that Dr. Nye derived for the greatest height of an ice cap

$$
h=\sqrt{23^{x}}
$$

where $h=$ height in $\mathrm{m}$. and $x=$ radius at base in $\mathrm{m}$., and assuming that the North East Land ice cap 
Sørfonna is circular in plan, and of approximately 14 miles radius on a flat base $300 \mathrm{~m}$. above sea level, all of which is reasonable as a first approximation, then the maximum height attained comes out at $740 \mathrm{~m}$. above sea level approximately. The height was found by Professor Ahlmann in $193 \mathrm{r}$ to be $764 \mathrm{~m}$.

Dr. NyE: I am grateful to Mr. Hartog for pointing out this satisfying agreement. The fact that the formula for a horizontal bed and with $2 h_{0}=23 \mathrm{~m}$. fits the observed height shows that the average shear stress on a horizontal plane passing through the edge of the ice cap is close to $\mathrm{I}$ bar.

\section{THE COLD ICE TUNNEL ON THE S ILBERSATEL, MONTE ROSA}

\section{953 P R O G R S S}

DURING the summer of 1953 progress on the tunnel was advanced from a length of about $60 \mathrm{~m}$. to close to $100 \mathrm{~m}$., notwithstanding considerable set-backs caused by bad weather.

On reopening the tunnel in June 1953 , it was found that the axis of the tunnel had been twisted horizontally and warped vertically as much as three or four meters from its original line; the cross-section of the innermost part of the tunnel, formerly $2 \mathrm{~m}$. high and $\mathrm{I} \mathrm{m}$. wide, had been compressed to approximately $\mathrm{I} \cdot 20 \mathrm{~m}$. high and $0.75 \mathrm{~m}$. wide.

Notwithstanding the exposure of the inner walls of the tunnel to air for nearly twelve months, no substantial change in the temperatures of the ice walls was noted on reopening the tunnel (see Fournal of Glaciology, Vol. 2, No. 13, April 1953, p. 194-96, for temperature measurements in 1952).

After re-excavating the 1952 structure to full size, progress was advanced during 1953 to a total length of close to $100 \mathrm{~m}$., and it is estimated that there is over $70 \mathrm{~m}$. of névé overlying the tunnel at its heading, which would represent a pressure of approximately roo lb./sq. in. $(7 \cdot 03$ $\left.\mathrm{kg} . / \mathrm{cm} .{ }^{2}\right)$. It was therefore with much surprise that quite a few voids were opened up in this far-in position of the tunnel, voids up to one cubic foot in volume. There was, of course, no unbalanced air pressure in the voids as the bubbly nature of the névé would not permit air under pressure. Occasional small stones of the size of a man's fist were often found; presumably they were dislodged by the wind during the former lower horizons of the glacier, and were not scoured out from the bed. The temperature of the ice walls throughout this entire advance of the tunnel in I 953 was uniformly between $7^{\circ}$ and $8^{\circ} \mathrm{F}$. $\left(-\mathrm{I} 3.9^{\circ}\right.$ to $-\mathrm{I} 3.3^{\circ} \mathrm{C}$.).

It is expected to continue the tunnel, with the benefits of these two years of experience, during the summer of 1954 , and it is hoped to reach bed-rock before the end of this coming summer.

Parallax in photographs of the location of the portal of the tunnel in I953, compared with identical photographs in $195^{2}$, indicates movement of about $35 \mathrm{~m}$. per annum for this highaltitude glacier. The location of the portal (see photograph on p. I94 of the reference cited above) has since been triangulated from the Gornergrat Stockhorn, so that accurate data on this movement will be available in 1954 .

MS. received 29 December 1953.

Joel E. Fisher 